\title{
Fluorescence as a guide to bronchial biopsy
}

\author{
JP HOMASSON, JP BONNIOT, M ANGEBAULT, P RENAULT, F CARNOT, G SANTELLI
}

From the Centre de Pneumologie, Chevilly-Larue, France

ABSTRACT The presence of fluorescence was assessed in 34 unselected patients undergoing bronchoscopy, 11 of whom suffered from bronchial carcinoma. Bronchoscopic inspection was carried out with white light and then repeated with blue light after the injection of $2 \mathrm{ml}$ of $10 \%$ sodium fluoresceinate. Fluorescence was graded visually. Seventy six pairs of biopsy specimens were obtained. Of 38 specimens from non fluorescent areas, histological appearances were normal in 34. Slight inflammation was observed in three biopsy specimens, and in one there was evidence of tumour even though the specimen was obtained some distance from the primary tumour. Of 38 biopsy specimens from fluorescent areas, histological examination showed appearances of moderate inflammation in 10, severe inflammation in 10, tuberculosis in one, and carcinoma in 11 . In six instances histological appearances were normal. Five normal subjects who were smokers were also examined by the same technique. Appearances of metaplasia were found more often in areas showing fluorescence than in areas not showing fluorescence. Bronchial fluorescence is considered to be related to alteration in vascularity and is not specific for carcinoma. The most fluorescent areas are generally the most pathological and visible tumour is very fluorescent, but moderate degrees of fluorescence are difficult to interpret. Biopsy of every fluorescent area seems excessive.

Fibreoptic bronchoscopy usually enables a histological diagnosis to be made in patients with proximal bronchogenic carcinoma. Small tumours, however, cannot be detected radiologically and invasion of the mucous membrane may be invisible at endoscopy. For some years now the use of fluorescent substances has been explored in an attempt to improve the localisation of these lesions. Fluorescent substances can be difficult to use. Tetracycline ${ }^{12}$ requires several days of preliminary treatment before bronchoscopy; the derivatives of haematoporphyrin ${ }^{3}$ injected into the veins give variable results, injection is required 48-96 hours before examination and there is a high risk of photosensitivity. Inhaling fluorescein ${ }^{4}$ has given good results but the technique is difficult and requires the use of a rigid bronchoscope and general anaesthesia.

We have devised a simple technique resembling that used by urologists ${ }^{s}$ that could eventually be used routinely in fibreoptic bronchoscopy. We pres-

Address for reprint requests: Dr JP Homasson, Centre de Pneumologie, 24 Rue Albert Thuret, 94550 Chevilly Larue, Val de Marne, France.

Accepted 13 August 1984 ent results obtained in 34 patients with various respiratory diseases.

\section{Methods}

We used $10 \%$ fluorescein in the form of sodium fluoresceinate; $2 \mathrm{ml}$ of the solution is injected intravenously. Reported side effects ${ }^{6}$ are rare; the risks of nausea and vomiting may be averted by an intramucuslar injection of metoclopramide half an hour before bronchoscopy. An intravenous injection of corticosteroid is given immediately before the injection of colouring.

Bronchoscopic inspection is first undertaken in white light and is then repeated in blue light after the injection of fluorescein. This blue light is obtained by interposing a filter between the Storz light source and the fibreoptic bronchoscope. In this study a yellow filter was not used on the endoscope eyepiece. A yellow fluorescence appears $30-45 \mathrm{sec}-$ onds after the injection and lasts for 5-7 minutes, during which time biopsy can be undertaken. Abnormal areas which might be suitable for biopsy appear yellow on a blue background.

We have used the technique in 34 unselected patients who required bronchoscopy irrespective of 
the underlying respiratory disease. The working clinical diagnoses were: carcinoma (11 cases), chronic bronchitis (3), pulmonary tuberculosis (4), asthma (1), bronchiectasis (1), acute pneumonia (1), obscure haemoptysis (2), obscure chest pain (1), cough (1). Five healthy subjects volunteered to participate in a study of precancerous metaplasia. ${ }^{4}$ Patients entered the study after their informed consent had been obtained.

In every subject in which a fluorescent area was seen at least two biopsy specimens were obtained (one from a fluorescent and one from a nonfluorescent area). The fluorescence was graded by two bronchoscopists, the grading being: intense fluorescence $(+)$, slight fluorescence $( \pm)$, and no fluorescence $(-)$. The pathologist was aware whether a specimen came from a fluorescent or a non-fluorescent area. Under white light the endoscopic appearances were divided into types: normal, visible tumour, and inflammation. The Société Française de Pneumologie defines three stages of inflammation of the bronchial mucosa according to the thickness, colour, and vascular congestion and these criteria are used in this study.

The five men who volunteered to be examined with a view to detecting precancerous lesions (metaplasia) were healthy smokers; these subjects entered a larger study of 70 patients. ${ }^{7}$ They had had more than 15 pack years of smoking experience. Each underwent a careful examination by fibreoptic bronchoscopy, during which 10 biopsy specimens were taken on the 10 main bifurcations of the bronchial tree. The pathologist was informed of the presence or absence of fluorescence for each bifurcation biopsied. Fluorescent areas in other parts of the bronchial tree were also biopsied. Each biopsy specimen was cut into five to 10 serial sections $4 \mu \mathrm{m}$ thick. An index of metaplasia (IM), expressed as a percentage, was calculated as follows:

$$
\mathrm{IM}=\frac{\text { number of sections with metaplasia }}{\text { number of sections examined }} \times 100 .
$$

\section{Results}

In the 29 subjects with pulmonary disease we undertook 76 biopsies. Of 38 non-fluorescent areas, the bronchial biopsy specimen showed normal appearances in 34 cases; in three cases moderate inflammation was seen; in one case (no 3 ) occult tumour was identified. The biopsy specimen in question was taken at some distance from the primary lesion.

Of 38 fluorescent areas, biopsy showed appearances of moderate bronchial inflammation in 10 specimens, severe inflammation (sometimes metaplasia) in 10, and bronchial tuberculosis in one (although the bronchus was not inflamed to any serious degree under white light). Appearances of carcinoma were present in 11 biopsied fluorescent areas and in six the histological appearances were normal (table).

The level of fluorescence was variable in these 29 patients. Fluorescence was intense in 14 cases $(+)$, much less so in $10( \pm)$, and non-existent in five $(-)$. When intensity was low, histological examination in nine cases out of 10 revealed non-neoplastic pathol-

Results of bronchoscopic biopsy guided by fuorescence in 11 patients with carcinoma of the lung

\begin{tabular}{|c|c|c|c|c|c|c|c|c|c|}
\hline \multirow{2}{*}{$\begin{array}{l}\text { Patient } \\
\text { No }\end{array}$} & \multirow[t]{2}{*}{ Sex } & \multirow{2}{*}{$\begin{array}{l}\text { Age } \\
(y)\end{array}$} & \multirow[t]{2}{*}{ Radiological appearances } & \multirow{2}{*}{$\begin{array}{l}\text { Endoscopic } \\
\text { appearances }\end{array}$} & \multirow[t]{2}{*}{ Fluorescence } & \multicolumn{2}{|c|}{ Non-fuorescent areas } & \multicolumn{2}{|c|}{ Fluorescent areas } \\
\hline & & & & & & $\begin{array}{l}\text { No of } \\
\text { biopsies }\end{array}$ & $\begin{array}{l}\text { Histological } \\
\text { appearances }\end{array}$ & $\begin{array}{l}\text { No of } \\
\text { biopsies }\end{array}$ & $\begin{array}{l}\text { Histological } \\
\text { appearances }\end{array}$ \\
\hline 1 & $\mathbf{M}$ & 52 & $\begin{array}{l}\text { Left upper lobectomy for } \\
\text { squamous cell carcinoma } \\
2 \text { years before }\end{array}$ & normal & - & 3 & normal & 0 & - \\
\hline 2 & $\mathbf{F}$ & 54 & $\begin{array}{l}\text { Right metastatic pleural } \\
\text { disease }\end{array}$ & normal & \pm & 1 & normal & 1 & $\begin{array}{l}\text { Severe } \\
\text { inflammation }\end{array}$ \\
\hline 3 & $\mathbf{M}$ & 56 & Mass left upper lobe & visible tumour & + & 1 & $\begin{array}{l}\text { Carcinomatous } \\
\text { lymphangitis }\end{array}$ & 2 & $\begin{array}{l}\text { Carcinomatous } \\
\text { lymphangious }\end{array}$ \\
\hline 4 & $\mathbf{M}$ & 62 & $\begin{array}{l}\text { Right pneumonectomy for } \\
\text { squamous cell carcinoma }\end{array}$ & normal & + & 1 & normal & 1 & $\begin{array}{l}\text { normal mucous } \\
\text { membrane }\end{array}$ \\
\hline $\begin{array}{l}5 \\
6\end{array}$ & $\begin{array}{l}\mathbf{M} \\
\mathbf{M}\end{array}$ & $\begin{array}{l}76 \\
62\end{array}$ & $\begin{array}{l}\text { Right hilar enlargement } \\
\text { Right hilar enlargement }\end{array}$ & $\begin{array}{l}\text { visible tumour } \\
\text { visible tumour }\end{array}$ & $\begin{array}{l}+ \\
+\end{array}$ & $\begin{array}{l}2 \\
2\end{array}$ & $\begin{array}{l}\text { normal } \\
\text { normal }\end{array}$ & $\begin{array}{l}2 \\
3\end{array}$ & $\begin{array}{l}\text { Adenocarcinoma } \\
\text { Metaplasia }\end{array}$ \\
\hline 7 & $\mathbf{M}$ & 74 & Atelectasis of left lower & visible tumour & + & 1 & normal & 2 & Oat cell carcinoma \\
\hline 8 & $\mathbf{M}$ & 43 & Mass right middle lobe & visible tumour & + & 1 & Inflammation & 1 & Squamous cell \\
\hline 9 & $\mathbf{M}$ & 65 & Mass right upper lobe & visible tumour & + & 0 & - & 2 & Squamous cell \\
\hline 10 & $\mathbf{M}$ & 52 & Mass left lower lobe & visible tumour & + & 1 & normal & 1 & $\begin{array}{l}\text { Poorly } \\
\text { differentiated } \\
\text { carcinoma }\end{array}$ \\
\hline 11 & $\mathbf{M}$ & 40 & Mass left lower lobe & visible tumour & + & 1 & normal & 1 & Adenocarcinoma \\
\hline
\end{tabular}


ogy. Intense fluorescence was seen in nine patients with carcinoma, one with tuberculosis, and four with other benign pathology (cough, pneumonia, and chronic bronchitis). Lesions due to tumour are very fluorescent, which makes it possible to locate the biopsy sites; in eight cases the tumour was visible under white light; in one case microscopic tumour lesions were detected away from the tumour, whereas the bronchial mucosa showed only appearances of inflammation in this area (case 5). Low intensity fluorescence was generally associated with histological features of inflammation.

Among the smokers who volunteered for the study the level of fluorescence was generally low. Three hundred and forty three sections were examined. Ninety seven sections showed appearances of metaplasia. Appearances of metaplasia were found in 31 of 68 areas $(45 \%)$ showing fluorescence and in only 66 of $275(24 \%)$ of areas which did not show fluorescence $\left(p<0.001, \chi^{2}\right.$ test).

No complications due to the injection of fluorescein were noted.

\section{Discussion}

The method is of interest because of its simplicity and harmless nature. It appears to be possible to position biopsy attempts in areas which might not attract attention under white light. Although in this small preliminary series the technique did not lead to a diagnosis of bronchial carcinoma where such a diagnosis had not already been made, we are impressed by the histological results obtained in fluorescent areas where the appearances in white light did not suggest tumour. More extensive study is certainly required, but it seems at least possible that the technique could find a role in the diagnosis of in situ carcinoma or in the identification of tumour spread beyond the extent visible in white light.

The absence of pharmacokinetic studies of fluorescein limits interpretation of the findings. Fluorescent areas are likely to be related to modifications of vascularistion and not to specific staining of tumour cells. Fluorescence using haematoporphyrin is also not specific for car- cinoma. ${ }^{8}$ Nevertheless, the most fluorescent areas are generally the most pathological and macroscopically visible tumours are extremely fluorescent. There is a considerable range of more or less intense fluorescence which requires subjective interpretation on the operator's part, a task corresponding to the assessment of degrees of inflammation. At present to biopsy every fluorescent area seems excessive. Nevertheless, our study on the degree of bronchial metaplasia encountered in heavy smokers subjected to multiple biopsies? is of interest, and future experience may show that there are circumstances where biopsy of every fluorescent area is worthwhile.

A table setting out details of the patients without carcinoma of the lung has been lodged with the editor and copies are available from the authors.

We thank Storz SA France for its assistance.

\section{References}

1 Rall DP, Loo TL, Lane M, Kelly MG. Appearance and persistance of fluorescent material in tumour tissue after tetracycline administration. J Natl Cancer Inst 1957; 19:79-85.

2 McLeay JF. The use of systemic tetracyclines and ultraviolet in cancer detection. Am J Surg 1958;96:414-9.

3 Doiron DR, Profio E, Vincent RG, Dougherty TJ. Fluorescence bronchoscopy for detection of lung cancer. Chest 1979;76:27-32.

4 Hürzeler D. Ultraviolet fluorescence bronchoscopy in early detection of bronchogenic carcinoma. Ann Otol Rhinol Laryngol 1978;87:528-32.

5 Vallancien G. La cystoscopie en lumière fluorescente. Nouv Presse Méd 1981;10:3791-2.

6 Coscas G, Binaghi M, Faure M. Incidents et accidents au cours de l'angiographie en fluorescence. In: Conférences lyonnaises d'ophtalmologie No 145. Annonay, France: Laboratory H Faure, 1980.

7 Gouveia J, Hercend T, Lemaigre G, et al. Degree of bronchial metaplasia in heavy smokers and its regression after treatment with a retinoïd. Lancet 1982;i:710-2.

8 Cortese DA, Kinsey JH, Woolner LB, Sanderson DR, Fontana RS. Hematoporphyrin derivative in the detection and localisation of radiographically occult lung cancer. Am J Respir Dis 1982;126: 1087-8. 